\title{
Use of ion chromatography method on the determination of some anions in the water collected from Sakarya, Turkey
}

\author{
Huseyin Altundag $\odot^{1 *}$, Serife Agar $\oplus^{1}$, Esra Altıntıg $\oplus^{1}$, Asude Ates $\oplus^{2}$ and \\ Sezen Sivrikaya ${ }^{3}$
}

\author{
${ }^{1}$ Sakarya University, Faculty of Arts and Sciences, Department of Chemistry, 54187, Sakarya, Türkiye \\ ${ }^{2}$ Sakarya University, Faculty of Engineering, Department of Environmental Engineering, 54187, \\ Sakarya, Türkiye \\ ${ }^{3}$ Duzce University, Faculty of Technology, Department of Polymer Engineering, 81620, Duzce, \\ Türkiye
}

(Received March 19, 2019; Revised May 16, 2019; Accepted May 20, 2019)

\begin{abstract}
In this study simultaneous analysis of seven different anions (Fluoride, Chloride, Bromide, Nitrite, Nitrate, Phosphate, and Sulfate) in13 different water samples collected from Sakarya/Turkey and it was conducted with ion chromatography method. Analyzes were performed simultaneously using the ion chromatography method. Some validation tests and the optimum conditions for the determination of anions were studied. The analysis of anions was accomplished by the dilution of the sample injection device. Samples were used to adjust the terms of the device and the results were recorded. Ion chromatography (IC) is now considered as an excellent technique for the analysis of ions in many samples.
\end{abstract}

Keywords: Water; ion chromatography; anion; Sakarya. . ( 2019 ACG Publications. All rights reserved

\section{Introduction}

Water is one of the essential elements of life which is an environment for living creatures [1]. It is provided from sources such as rivers, ponds, artificial reservations, dams, underground water sources and spring water. The supply of water from surface sources is prone to air pollution, spillage and other occasional contaminants in the watershed, and changes in weather conditions, while groundwater is generally less susceptible to occasional inputs of contaminations, and more likely reflects the nature of the detrital material of the aquifer. Surface water is used in homes, is discharged in agricultural areas and used for industrial waste treatment and as a resource for human use [2]. Supplying water of the desired quality and ensuring sustainability may occur as a result of monitoring by health authorities and distribution companies in terms of the features of the resource [3].

The characteristics of water change during the water recycling process. For example, rainwater contains $\mathrm{Cl}^{-}, \mathrm{SO}_{4}{ }^{2-}, \mathrm{HCO}_{3}{ }^{-}$anions in addition to cations such as $\mathrm{Na}^{+}, \mathrm{K}^{+}, \mathrm{Mg}^{2+}$ as the result of the dust and other materials in the air, with the exception of gases in the atmosphere. Underground and spring waters may contain several materials in addition to these cations and anions depending on the geological and chemical structure of the area [4]. Anions with the exception of fluoride, chloride, bromide, iodide and sulfite are formed by a chemical reaction using more than one element. The stability and the reaction tendencies of anions differ. But it is possible to say that anions are more

\footnotetext{
*Corresponding author E-Mail: altundag@ sakarya.edu.tr
} 
reactive than cations $[3,5]$. The toxicity level of anions (nitrites, nitrates, brome, bromate, sulfate, phosphate, fluorine and chloride) is crucial for human and environmental health. During the disinfection process, chlorine can react with effluent organic matter and use bromide and iodine ions to form a variety of disinfection byproducts [6-8]. Nitrite and nitrate are found in trace concentrations in the bulk matrices such as in high salinity, seawater, and in industrial and agricultural water. Nitrates and nitrites are due to the run-off of nitrogenous fertilizers, leaching from septic tanks and sewage sites. Nitrates can induce methaemoglobinemia [9].

Ion Chromatography (IC) is an efficient and sensitive analytical method that has recently been used in order to separate, identify and determine the chemical compounds in mixtures $[10,11]$. The concentrations of the compounds emerging from the stable phase are measured accurately, and graphics referred to as a "chromatogram" are formed by marking on the y axis across the used value of the mobile phase or time.

Synchronous analysis of the seven different anions (Fluoride, Chloride, Bromide, Nitrite, Nitrate, Phosphate and Sulfate) in the 13 water samples collected from around Sakarya was performed using the ion chromatography method. Optimum conditions were researched for a variety of validation tests and for the analysis of the anions. The analysis of the anions was performed via injection of the samples into the device after a concentration procedure. The conditions of the device were adjusted and samples were read, and the results were recorded. Ion chromatography was accepted as a perfect technique for the determination of the ions in various samples.

\section{Experimental}

\subsection{Chemical and Reagents}

Water samples were collected from 13 different places between October 2014 and October 2015. Samples of bottled water and mineral waters were collected from various markets in Sakarya. These samples brought to the laboratory have been passed from pretreatment to obtain suitable conditions for the analysis methods for various parameters. These were stored in a refrigerator at +4 ${ }^{\circ} \mathrm{C}$. $\mathrm{pH}$ was measured with a heat control $\mathrm{pH}$ meter with the sensitivity of 0.01 measurement capability (Metler Toledo MP120. The pH meter was calibrated routinely using buffer tablets (Fisher Scientific) of 4.0, 7.0 and $9.2 \mathrm{pH}$. First, the $\mathrm{pH}$ levels of the samples were checked. All the reagents were analytical grade. Double deionized water was used for all dilutions.

$1000 \mathrm{mg} / \mathrm{L}$ Fluoride, Chloride, Bromide, Sulfate, Phosphate, Nitrate and Nitrite were prepared by dissolving an appropriate amount of their corresponding sodium salts at $99.9 \%$ purity (Merck,

Darmstadt, Germany) in water. Six point calibrations were done with standards for each anion concentration (1-1000 mg/L). 9-10 $\mathrm{Mm} \mathrm{Na}_{2} \mathrm{CO}_{3}$ was used as an eluent.

\subsection{Apparatus}

Analysis was performed via DIONEX ICS-3000 DC Ion Chromatography. The column pressure of the device is $1800 \mathrm{psi}$, and the eluent flow rate is $1.0 \mathrm{~mL} \mathrm{~min}^{-1}$. The specifications of the devices are listed in Table 1. 
Table 1. Operation conditions for DIONEX: ICS-3000

\begin{tabular}{ll}
\hline Column & Dionex IonPac AS9-HC \\
\hline Eluent & $9-10 \mathrm{Mm} \mathrm{Na}_{2} \mathrm{CO}_{3}$ \\
Flow rate & $1.0 \mathrm{~mL} / \mathrm{min}$ \\
Injection volume & $25 \mu \mathrm{L}$ \\
Suppressor & Dionex ASRS $3002 \mathrm{~mm}$ \\
Column temperature & $35^{\circ} \mathrm{C}$ \\
Detection & Conductivity \\
Determination mode & Peak-area \\
\hline
\end{tabular}

\subsection{Sample Collection and Preparation}

Drinking water and mineral water samples were bought from supermarkets and tap water samples were obtained from Sakarya in Turkey. These samples were analyzed without any dilution.

\section{Result and Discussion}

Anions in 13 different water samples that were examined using with Ion Chromatography device is as shown in Table 2. It was observed that some of these determined anions were not found. When the $\mathrm{pH}$ values of these 13 water samples were considered, many of these samples were determined as being basic. $\mathrm{pH}$ is the measure of the hydronium $\left(\mathrm{H}_{3} \mathrm{O}^{+}\right)$ion in the water and shows the balance between the acid and base in the water. Carbonate and hydroxide bicarbonate ions in water increase the alkalinity and carbonic acid increases the acidity of the water. High $\mathrm{pH}$ value causes light smell in drinking water. Color intensity increases with the $\mathrm{pH}$ increase. The detection limits are 0.15 $\mathrm{mg} / \mathrm{L}$ for $\mathrm{Br}^{-}, 0.07 \mathrm{mg} / \mathrm{L}$ for $\mathrm{Cl}^{-}, 0.01 \mathrm{mg} / \mathrm{L}$ for $\mathrm{F}^{-}, 0.07 \mathrm{mg} / \mathrm{L}$ for $\mathrm{NO}_{2}{ }^{-}, 0.20 \mathrm{mg} / \mathrm{L}$ for $\mathrm{NO}_{3}{ }^{-}, 0.10 \mathrm{mg} / \mathrm{L}$ for $\mathrm{SO}_{4}{ }^{2-}, 0.08 \mathrm{mg} / \mathrm{L}$ for $\mathrm{PO}_{4}{ }^{3-}$.

Table 2. Analysis results of anions (mg/L)

\begin{tabular}{|c|c|c|c|c|c|c|c|c|}
\hline Sample & Bromide & Chloride & Fluoride & Nitrite & Nitrate & Sulfate & Phosphate & $\mathrm{pH}$ \\
\hline Bottle Water & N.D & 0.08 & 0.01 & N.D. & N.D. & N.D. & N.D. & 7.50 \\
\hline $\begin{array}{l}\text { Ultra-Pure } \\
\text { Water }\end{array}$ & N.D. & 0.24 & 0.02 & 0.11 & 0.22 & N.D. & 0.08 & 7.20 \\
\hline Tap Water & N.D. & 11.46 & 0.08 & 0.13 & 0.72 & N.D. & 1.71 & 7.87 \\
\hline $\begin{array}{l}\text { Sakarya } \\
\text { River }\end{array}$ & 0.18 & 78.52 & 0.33 & N.D. & 920 & 0.62 & 2.75 & 6.80 \\
\hline $\begin{array}{l}\text { Dispenser } \\
\text { Size Water }\end{array}$ & N.D. & 3.29 & 0.03 & 0.11 & 11.46 & N.D. & 2.40 & 7.20 \\
\hline Pool Water & N.D. & 110.07 & 0.19 & N.D. & N.D. & N.D. & 4.56 & 7.20 \\
\hline $\begin{array}{l}\text { Sapanca } \\
\text { Lake }\end{array}$ & N.D. & 11.18 & 0.15 & N.D. & N.D. & N.D. & 1.81 & 7.80 \\
\hline Spring Water & N.D. & 21.06 & 0.33 & N.D. & 4.92 & N.D. & 2.51 & 7.50 \\
\hline In Well & N.D. & 22.69 & 0.27 & N.D. & 10.77 & 2.49 & 33.65 & 7.79 \\
\hline Stream Water & N.D. & 15.87 & 0.45 & N.D. & 2.77 & N.D. & 5.97 & 7.36 \\
\hline Well Water & N.D. & 27.74 & 0.20 & N.D. & 3.97 & 0.17 & 48.51 & 7.50 \\
\hline Rock Water & N.D. & 12.79 & 0.06 & N.D. & 5.11 & N.D. & 3.43 & 7.49 \\
\hline Rain Water & N.D. & 7.02 & 0.76 & N.D. & 4.62 & N.D. & 4.12 & 6.65 \\
\hline
\end{tabular}

N.D: Not Detected 
Table 3. Acceptable maximum quality parameter values of drinking and mineral water

\begin{tabular}{|c|c|c|c|c|c|}
\hline \multicolumn{5}{|c|}{ Drinking Water $(\mathrm{mg} / \mathrm{L})$} & \multirow[b]{2}{*}{$\begin{array}{c}\text { Mineral Water } \\
\text { (mg/L) } \\
\text { TSE 9130 }\end{array}$} \\
\hline Anions & $\begin{array}{l}\text { TSE } 266 \\
\text { Institute of } \\
\text { Turkish } \\
\text { Standards }\end{array}$ & $\begin{array}{c}\text { EU } \\
\text { European } \\
\text { Union }\end{array}$ & $\begin{array}{c}\text { WHO } \\
\text { World Health } \\
\text { Organization }\end{array}$ & $\begin{array}{c}\text { EPA } \\
\text { Environmental } \\
\text { Protecting } \\
\text { Agency }\end{array}$ & \\
\hline NITRATE $\left(\mathrm{NO}_{3}^{-}\right)$ & $25-50$ & 50 & 50 & 45 & 25 \\
\hline NITRITE $\left(\mathrm{NO}_{2}^{-}\right)$ & 0.5 & 0.5 & 0.5 & - & $0.20-0.05$ \\
\hline FLOURIDE $\left(\mathrm{F}^{-}\right)$ & $1-1.5$ & 1.5 & 1.5 & $0.7-2.4$ & $1.0-2.0$ \\
\hline CHLORIDE $\left(\mathrm{Cl}^{-}\right)$ & 600 & 250 & 250 & 250 & 134 \\
\hline SULFATE $\left(\mathrm{SO}_{4}{ }^{2-}\right)$ & $25-250$ & 250 & 250 & 250 & 106 \\
\hline PHOSPHATE $\left(\mathrm{PO}_{4}{ }^{3-}\right)$ & $0.4-5$ & $0.4-5$ & - & - & - \\
\hline BROMIDE (Br-) & 0.01 & - & - & 0.01 & - \\
\hline $\mathrm{pH}$ & $6.5-9.5$ & $6.5-9.5$ & $6.5-8.5$ & $6.5-8.5$ & $5.38-8.79$ \\
\hline
\end{tabular}

When the Table 3 was examined it was determined that $\mathrm{pH}$ values in the water samples were in TSE, EC, WHO and EPA standards. According to this table $\mathrm{pH}$ level of the samples varies between 5.38 and 9.5. According to the drinking water parameters (TSE 266, EC, WHO, EPA), standard values are as in Table 3 . Water quality parameters are as in Table 4.

Table 4. Water quality classes

\begin{tabular}{lcccc}
\hline Water Quality Parameters & \multicolumn{4}{c}{ Water Quality Classes } \\
\hline Physical and Inorganic-Chemical & I & II & III & IV \\
\hline $\mathrm{pH}$ & $6.5-8.5$ & $6.5-8.5$ & $6.0-9.9$ & except $6.0-9.0$ \\
Chloride ion $(\mathrm{mg} / \mathrm{L})$ & 25 & 200 & 400 & $>400$ \\
Sulfate ion $(\mathrm{mg} / \mathrm{L})$ & 200 & 200 & 400 & $>400$ \\
Inorganic Contamination Parameters & & & & \\
Fluoride $(\mathrm{mg} / \mathrm{L})$ & 1000 & 1500 & 2000 & $>2000$ \\
Free Chloride $\left(\mu \mathrm{g}, \mathrm{Cl}_{2}\right)$ & 10 & 10 & 50 & $>50$ \\
\hline
\end{tabular}

Water quality classes are presented in Table 4 . When the results of the 13 water samples were examined, the bromide level was not determined in 12 samples, it was found to be $0.18 \mathrm{mg} / \mathrm{L}$ in the sample of Sakarya River and $0.45 \mathrm{mg} / \mathrm{L}$ in the sample of mineral water.

Bromine is a trace element of some rock forming minerals such as biocide, amphiboles, apatite, eudialyte and sodalities, mostly as a replacement for $\mathrm{Cl}$. Coal and organic matter accumulate $\mathrm{Br}$ and some sedimentary rocks can show elevated $\mathrm{Br}$ concentrations. Bromide is the most common form of bromine in the aqueous environment, and is highly enriched in the marine environment, with ocean waters having a mean concentration of $67.000 \mu \mathrm{g} / \mathrm{L}$. It has a geochemistry very similar to that of chloride [3]. Ozonizing source water that contains elevated levels of natural bromide can produce the bromate. Both the World Health Organization (WHO) and the US Environmental Protection Agency (EPA) have listed bromate as a potential carcinogen at the low $\mu \mathrm{g} / \mathrm{L}$ level [12]. The maximum recommended bromide level of drinking water is $10 \mu \mathrm{g} / \mathrm{L}$ dir. High bromide concentrations can also be expected in natural brines and thermal waters. Low level of bromide which was examined in our study was evaluated as a positive result.

Chlorination is a common disinfection method in drinking water treatment [13]. The highest chloride concentration values were determined in the pool water at $110.07 \mathrm{mg} / \mathrm{L}$. The lowest chloride value was determined in the case of bottled water with $0.08 \mathrm{mg} / \mathrm{L}$. It is lower than the highest value of 
$600 \mathrm{mg} / \mathrm{L}$ determined as being the standard values. The determined chloride levels were deemed to be standards.

Fluoride is one of the required trace elements for human beings, but high fluoride concentrations are highly toxic and may cause death because they block various enzymes [14]. Fluorine is therefore mostly retained in minerals and rocks in the lithosphere [15]. Due to these consequences, it is important to determine the fluorine concentrations in many matrices. In our study, the fluoride level was determined to be below the $2.4 \mathrm{mg} / \mathrm{L}$ level which is determined as the standards of TSE, EC, WHO and EPA. The highest fluoride level was determined in the mineral water at 1.14 $\mathrm{mg} / \mathrm{L}$. The lowest fluoride level was determined in the bottled water at $0.01 \mathrm{mg} / \mathrm{L}$. The determined fluoride values are considered to be caused by the contaminators around the lake and by the fluoride levels in the naturel state.

Nitrites may react with secondary and tertiary amines forming highly carcinogenic nitrosamines. Therefore, the permissible level of nitrite is $0.1 \mathrm{mg} / \mathrm{L} \mathrm{[16].} \mathrm{In} \mathrm{this} \mathrm{study} \mathrm{nitrite} \mathrm{levels}$ were not determined in the bottle water, the Sakarya River, dispenser size water, pool water, Sapanca Lake, spring water, well, stream water, well water, rock water and rain water. The lowest nitrite level was determined to exist in the dispenser size water at $0.11 \mathrm{mg} / \mathrm{L}$. The highest nitrite level was found in the mineral water at $1.52 \mathrm{mg} / \mathrm{L}$. Nitrite level in the samples were found suitable to the standards except mineral water.

The contamination of water sources with $\mathrm{NO}_{3}{ }^{-}$is a problem of increasing concern. The sources of nitrates in drinking water include effluent from wastewater treatment plants and septic systems, landfills and agricultural fertilizers [16]. The nitrate levels were not determined in the case of bottled water, pool water and Sapanca Lake water. The highest nitrate level was determined as $56 \mathrm{mg} / \mathrm{L}$ in Sakarya River water and the lowest nitrate level was determined in the ultra-pure water with 0.22 $\mathrm{mg} / \mathrm{L}$ in other water samples. The nitrate level in the samples was found below the standards, with the exception of Sakarya River. We hereby think that nitrate level of Sakarya River samples which exceeds the standards, caused because of the closeness to the agricultural areas. The presence of bromide in the coastal area water samples may be due to sea water intrusion and excess nitrate may be due to agricultural activity incorporating nitrogen fertilizer [17].

Sulfate is the most common anions in the water after bicarbonate and chloride. Since sulfates form $\mathrm{CaSO}_{4}$ and $\mathrm{MgSO}_{4}$ sediments in thermal water, they have to remain in small amounts in such water [18]. The sulfate levels were just determined in the Sakarya River, and in mill water. The sulfate levels in other samples were below the determination level. The highest determined sulfate levels were in mill water with $2.49 \mathrm{mg} / \mathrm{L}$ and the lowest were in the Sakarya River water with $0.62 \mathrm{mg} / \mathrm{L}$. This can be compared to the WHO standards which have determined the limit as $500 \mathrm{mg} / \mathrm{L}$ and the EU standard of $250 \mathrm{mg} / \mathrm{L}$. Even though TS 266 has mentioned these conditions, they are repealed in 2005 [19]. The results obtained are far below the determined limits, indicating that reason the sulfate amount are at an acceptable levels. Sulfate levels in all samples were below the various international standards.

Phosphate level was not determined in the water sample. The highest level of phosphate was determined in the mill water with $48.51 \mathrm{mg} / \mathrm{L}$ and the lowest level of phosphate was determined in the ultrapure water with $0.08 \mathrm{mg} / \mathrm{L}$. Phosphate levels in our study is at standard level except mill water. As the result of oscillation of over fertilization, agricultural land and industrial or municipal resources, increase of phosphor entrance to natural waters bring together the undesirable effects as eutrophication and exponential algal bloom causes harmful effects for the fish. Also the most bio-usable fraction was represented by orthophosphate that is generally soluble and reactive phosphorous of phosphorous type in the water. It is thought that high level of phosphate in the water environment is caused by the existence of essential nutrients in the environment for the biological production.

\section{Conclusions}

It is identified with the use of an ion chromatography device that some of the 7 different anions were not detected in 13 different water samples. When the results were examined in general sulfate, chloride and fluoride anions were found to be below the standard values. Bromide anion was just determined in the Sakarya River water and in mineral water, and it was determined to be higher than the standard values. Nitrate anion was determined as being at normal levels in the other water samples 
except the Sakarya River water. Phosphate anion was determined high in all of the samples with the exception of bottled water, ultra-pure water, rock water and rain water. The high level of phosphate is considered to be caused by the fact that it is a basic food element for aquatic environments and biological production. When we looked at the anion values these samples, most of them are not suitable with the parameter values in terms of drinking water quality. The reason for this may be explained by the fact that the water samples are not suitable for drinking. When these 13 water samples were examined in terms of $\mathrm{pH}$, it is possible to say that it can be separated into different water quality classes. In order to check the accuracy and repeatability of the analysis results, accuracy controls were calculated by using the standard addition technique as part of the chromatography method. When all results are examined, the ion chromatography technique is accepted as accurate, sensitive, proper and perfect technique for the determination of the ions in different samples.

\section{Acknowledgements}

We here by thank to Fatih Mehmet Kosar for language support for professional editing service for language of manuscript.

\section{ORCID}

Huseyin Altundağ: 0000-0002-3675-4133

Serife Agar: 000-0001-8809-3851

Esra Altıntığ:

Asude Ateș: 0000-0003-0934-0135

Sezen Sivrikaya: $\underline{0000-0003-4483-2880}$

\section{References}

[1] F. Brunato, M.G., Garziera and E Briguglio (2013). A severe methemoglobinemia induced by nitrats: a case report, Eur. J. Emerg. Med. 10, 326-330.

[2] N.F Gray (2008). Drinking Water Quality, Second Edition, Cambridge University Press.

[3] E. Dinelli, A. Lima, S. Albanese, M. Birke, D. Cicchella, L. Giaccio, P. Valera and B. De Vivo (2012). Major and trace elements in tap water from Italy, J Geochem Explor. 112, 54-75.

[4]. M. Doğan and M. Soylak (2000). Water Chemistry, Erciyes Üniversitesi Yayınları. Kayseri, 120, $132-150$

[5] H. Altundag, M.S Dundar, C. Yuceel and S, Albayrak (2011). Determination of fluoride levels of Sakarya city drinking water by ion-selective electrodes and ion chromatography, SAUJS 15, 129-138.

[6] X. Yang, C. Shang and J. Huang (2005). DPB formation in breakpoint chlorination of wastewater, Water Res. 39, 4755-4767.

[7] W.A.Mitch and D.L. Sedlak, (2002). Factors controlling nitrosamine formation during wastewater chlorination. Water Sci. Tech-W. Sup. 2, 191-198.

[8] I. Abusallout and G. Hua (2016). Natural solar photolysis of total organic chlorine, bromine and iodine in water, Water Res. 92, 69-77.

[9] W.Ren, S. Mura and J.M.K. Irudayaraj (2015). Modified graphene oxide sensors for ultrasensitive detection of nitrate ions in water, Talanta 143, 234-239.

[10] A.V. Zatirakha, A.D. Smolenkov and O.A. Shpigun (2016). Preparation and chromatographic performance of polymer-based anion exchangers for ion chromatography: A review, Anal. Chim. Acta, 904, 33-50.

[11] S.S. Khan and M. Riaz (2014). Determination of UV active inorganic anions in potable and high salinity water by ion pair reversed phase liquid chromatography, Talanta 122, 209-213.

[12] B.Zhu, Z. Zhong and J. Yao (2006). Ion chromatographic determination of trace iodate, chlorite, chlorate, bromide, bromate and nitrite in drinking water using suppressed conductivity detection and visible detection, J. Chromatogr. A 1118, 106-110.

[13] N. Ozbek and S. Akman (2012). Method development for the determination of fluorine in 
water samples via the molecular absorption of strontium monofluoride formed in an electrothermal atomizer, Spectrochim. Acta B 69, 32-37.

[14] S. Ayoob and A.K. Gupta (2006). Fluoride in drinking water: A Review on the status and stress effects. Crit. Rev. Env. Sci. Tec. 36, 433-487.

[15] N. Meyer, W.J. Parker, P.J. Van Geel and M. Adiga (2005). Development of an electrodeionization process for removal of nitrate from drinking water Part 2: Multi-species testing, Desalination 175, 167-177.

[16] T. Zhang, Y. Lin, B. Xu, S. Xi, F. Tian and N Gao (2016). Effect of UV irradiation on the proportion of organic chloramines in total chlorine in subsequent chlorination, Chemosphere 144, 940-947.

[17] H. Yalcin and M. Guru (2002). Water Technology. Palme Publishing, Ankara, 296.

[18] S. Zaruba, A.B. Vishnikin and V. Andruch (2015). Application of solidification of floating organic drop microextraction for inorganic anions: Determination of phosphate in water samples, Microchem. J. 122, 10-15.

[19] WHO Library Cataloguing-in-Publication Data Guidelines for drinking-water quality, (2011). 4th ed.

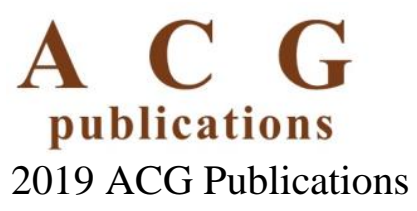

